Sharif University of Technology
Scientia Iranica
Transactions E: Industrial Engineering
http://scientiairanica.sharif.edu

\title{
A vehicle routing problem with two types of ships in container terminals
}

\author{
M. Safaeian, F. Etebari*, and B. Vahdani \\ Department of Industrial Engineering, Faculty of Industrial and Mechanical Engineering, Qazvin Branch, Islamic Azad University, \\ Qazvin, Iran.
}

Received 30 December 2019; received in revised form 14 February 2020; accepted 6 June 2020

\author{
KEYWORDS \\ Vehicle routing \\ problem; \\ Routing of ships; \\ Genetic algorithm; \\ Tramp ships; \\ Liner ships.
}

\begin{abstract}
The Vehicle Routing Problem (VRP) is one of well-established and important topics in supply chain and logistics networks. The location-routing decision-making has a significant role to optimize the traveling cost per distance, total traveling time, and the number of vehicles in the supply chain networks. One of the recent advances in these systems refers to container terminals in the global trade centers. The new contributions of this model are to consider the routes of two types of ships (Tramp and Liner) with different properties and the time windows in order to minimize costs, simultaneously. The proposed model is solved by an exact solver using LINGO software and because of inherent complexity of the problem proposed in the real-world cases, the Genetic Algorithm (GA) is used to find an optimal/global solution in a reasonable span of time. Finally, an in-depth analysis and discussion are provided to conclude the main findings and practical implications of the results.

(C) 2022 Sharif University of Technology. All rights reserved.
\end{abstract}

\section{Introduction and literature review}

The Vehicle Routing Problem (VRP) is one of the most essential and famous combinational optimization problems that has been studied extensively. This problem was first raised by Dantzig and Ramser as a critical issue in the field of transport distribution and logistics. It was shown that applying management methods and optimization issues in transportation had significant effect on reducing commodity costs [1]. A few years later, Clarke and Wright improved the results obtained by Dantzig and Ramser (1959) [1] by presenting a greedy heuristic approach [2]. A clear trend found in the vehicle routing studies of recent decades hovers around the transportation by trucks. In this regard, some of them are mentioned in this paper [3-5]. Coelho et al. investigated the routing

\footnotetext{
*. Corresponding author.

E-mail address: featebari@gmail.com (F. Etebari)
}

problem of a heterogeneous fleet that was allowed to travel multiple times [6]. Most notably, Lokukaluge et al. examined the impact of weather forecasts on the ship safety and found that ship safety could affect the ship's route speed. Also, taking the optimal route will result in reduced fuel consumption and, consequently, lower air pollution [7].

$\mathrm{Li}$ et al. investigated the VRP with heterogeneous fleet and open routes [8]. In this problem, the customers' demand is supplied by a fleet that possesses a certain number of vehicles with different capacities and related costs depending on the type of vehicle. With increase in the amount of freight, cost-effective management of fuel costs and daily operating costs for heterogeneous ships have become important issues [9]. This increase in sea freight between ports, besides fuel costs issue, has other consequences such as the emission of $\mathrm{CO}_{2}$ and $\mathrm{NO}_{x}$ gases. This environmental issue has recently drawn the attention of many media due to the negative impacts of climate change and air pollution. On the other hand, the cost of fuel and $\mathrm{CO}_{2}$ production is strongly dependent on the speed of 
the ships. Therefore, this study considers the type of the ships and the routing decisions based on the time windows intended to decrease costs.

From the last decade, there are many optimization models that have been developed to solve the Quay Crane problems. For example, Zhihong and $\mathrm{Na}$ [10] presented a nonlinear mathematical programming model to reduce the time of servicing for ships arriving at the terminal at horizon times, taking into account the non-crossing constraint of the quay cranes. Chen et al. [11] presented a mixed integer programming model that addressed the unique features of scheduling problem of allocating cranes in the indented berths. Legato et al. [12] proposed an improved model for the scheduling of quay cranes, taking into account factors such as the performance rate of each crane, safety requirements, precedence of containers, ready time, and due date of each crane, while the cranes can move in one direction (unidirectional cranes). Chen et al. [13] focused on a particular strategy for clusterbased quay crane scheduling problem associated with moving the unidirectional cranes in a timeline. By using this strategy called unidirectional quay crane scheduling problem in the literature, the problem of scheduling the quay cranes is enhanced. To solve the problem, they also used the state-of-the-art algorithm, which provided a better structure for searching for an optimal solution. Imai et al. [14] provided a strategy for Berth Template Problem (BTPS) to select ships from applicants for limited time horizons. Al-Dhaheri and Diabat [15] focused on the problem of scheduling the quay cranes to minimize the processing time for each vessel so that their goal was to present a way to reduce the differences between the container loads stacked over a number of bays and create a balance between ship bays in the loading and unloading operations. They also overcame the limitation of the unilateral movement of the quay cranes and made it possible for them to move on both sides, even when the operation of one bay has not been completed. Al-Dhaheri et al. [16] proposed a new model that considered the constraints of ship stability, crane displacement time, task preemption, and unidirectional movement of cranes. Because of the possibility of unexpected breakdown of cranes and a negative impact of cranes rescheduling on the planned berth, ship owners and crane operations. Liu et al. [17] studied the rescheduling of the crane with the aim of reducing negative deviations from the initial scheduling. Wu and $\mathrm{Ma}$ [18] focused on the problem of scheduling quay cranes by considering the draft and trim constraints, with the goal of minimizing loading time. Agra and Oliveira [19] presented an integrated model of berth allocation, quay crane assignment, and scheduling problem, which considered a set of heterogeneous cranes with discretion for time and space variables. The efficient operation of the terminal depends on proper planning of the container movement, called "stowage planning". Azevedo et al. [20] addressed the integrated problem of the 3D stowage planning problem and quay cranes scheduling problem in container vessels. Liang et al. [21] presented a coupling model to investigate the relationship between two aspects of the quay scheduling problem: task dispatch and quantity configuration of quay cranes. The first issue determines the loading sequence of cranes and the second issue determines the number of cranes allocated to each vessel. More recently, Safaeian et al. [22] developed an integrated Quay Crane Assignment and Scheduling Problem (QCASP) with Several Contractors. They applied a TeachingLearning-Based Optimization algorithm (TLBO) to solve the problem.

The remainder of this paper is organized as follows. Section 2 presents problem description, assumptions, notations, and mathematical formulation of the problem. Section 3 discusses the proposed Genetic Algorithm (GA). Section 4 provides computational results. Sections 5 concludes this paper and offers future directions.

\section{Problem statement}

In today's competitive world, lowering production costs and improving efficiency are among the priorities of industry managers' objectives and production policies, and each company tries to provide the best solutions to meet those needs. The success of many private, state, and military organizations depends on their ability to deliver optimal outputs, better products, and diverse services at a lower cost. The optimal delivery of these outputs (price, quality, performance, timely delivery, flexibility, and innovation) depends on the organization's ability to handle the exchange of materials, information, and money within and outside the organization. This exchange is known as supply chain and distribution networks. A vital issue in the supply chain is the use of methods that, in addition to managing and coordinating activities, improve and upgrade the supply chain. The objective of any distribution network model is to optimize the exchange among the network components. Therefore, based on the properties of the problem, the minimization of the objective function (usually of the cost type) is always taken into account, and these exchanges are manifested by customers' demand. Ideally, an appropriate distribution network design includes factors such as cost reduction, higher added value, and increased customer service by optimizing the communication between each node and its associated traffic flow. Establishing and simplifying these connections can reduce the total distance traveled in the network and improve the timing of loading and unloading sites. In the meantime, the issue 
of transportation (as a vital element of the distribution networks between the various components of the supply chain) plays a significant role in achieving the above goals. The primary purpose of transportation planning is to minimize the cost of transporting goods and materials between the producer and consumer levels. Regarding the type of the problem under study, factors such as the distance of the route, the quality of the route in terms of structure and environment, traffic congestion, vehicle capacity, customer demand, service level, etc. are taken into account. The issue of vehicle routing is at the heart of distribution management.

Maritime transport has a broader history than other types of transportation such as trains, cars, and planes. However, from the perspective of operations research/management science, limited research has been conducted on the ship routing problem, compared to much research done in the area of VRP. However, attention to maritime transport has increased in recent decades and gained much importance.

The ocean-going vessels are divided into three main groups:

1. Industrial ships: These are the most common ocean transportation ships used to transport bulk products. In this case, all loads must be serviced and the goal is to reduce operating costs;

2. Tramp ships: In tramp ships, the objective is to increase profits by choosing the right cargo for a fleet of ships. Tramp ships carry the shipments from one point to another (much like a taxi). Also, tramp ships serve temporary customers who have requested relocation. In this case, the cargos must be transferred directly from the loading port to the discharge port at a specified time. Usually, tramp ships carry the loads for one customer at one time;

3. Line ferries: Line ferries follow a timetable and itinerary similar to line buses and usually carry loads for a large number of customers.

In this study, a routing problem is presented along with the ship movement scheduling for cargo transfer. Tramp and liners are considered, and the capacity and travel time of each ship vary.

In this problem, the ports are considered in two forms of discharge and loading. A certain amount of one cargo is loaded in one port and unloaded in another.

Each cargo has specified number, time window, loading, and unloading ports. The scheduling company provides an itinerary for loading and discharge of the ships. Some cargoes may not be considered in the schedule and treated as spot cargoes and, so, being serviced by tramp vessels. Tamp vessels increase the costs incurred to the company, as the cost of shipping by tramp vessels is much more expensive than the

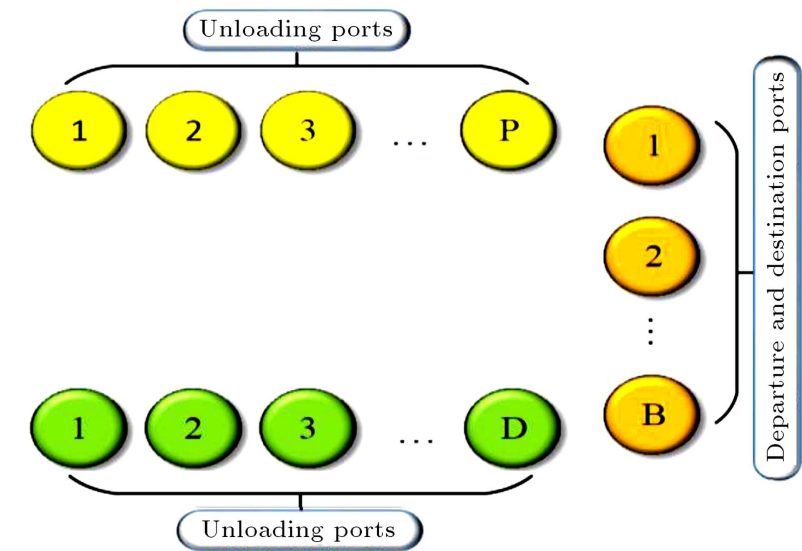

Figure 1. Graphical display of ship routing problem.

company vessels. Besides, it is difficult to determine the cost of tramp ships in the itinerary as the delivery schedule is set 45 days before the onset of each part, and the global economy is subject to frequent cost fluctuations. For this reason, planners try to use liners as much as possible and to use the tramp vessels the least. The cargoes can be separated and loaded by more than one ship (if they do not surpass their loading and unloading time windows). The cargo can also be loaded from multiple ports and unloaded into multiple ports. Figure 1 shows a general view of the routing shipping problem. As can be seen, the departure and destination ports are different from the loading and unloading ports.

\subsection{Assumptions}

The main assumptions in this explicit forms are as follows:

1. Liners and tramps are heterogeneous;

2. Tramp vessels are rented, if required;

3. Tramps can service one cargo (tramps can only load in one port, while liners can load multiple times during one trip);

4. All loads must be serviced;

5. Each cargo has specific loading and unloading ports;

6. Each loading and unloading port has a time window;

7. Each cargo can be serviced by tramp ships, liners, or both;

8. Each cargo can be serviced by more than one ship.

Table 1 defines the sets, parameters, and decision variables used in the formulation of the problem.

\subsection{Mathematical formulation}

The objective function of the problem and its restrictions is generally in the form of minimization and is as follows: 
Table 1. Sets, parameters, and decision variables.

\begin{tabular}{cl}
\hline Symbol & \multicolumn{1}{c}{ Mets } \\
\hline$P$ & A seaning \\
\hline$D$ & A set of ports where unloading takes place, $D=\{n+1, n+2, \cdots, 2 n\}$ \\
$E$ & A set of departure and destination ports of the ships, $E=\{2 n+1,2 n+2, \cdots, 2 n+B\}$ \\
$k$ & A set of ships, $K=\{1, \cdots, k\}$ \\
$N$ & A set of middle ports, $N=P \cup D$ \\
$V$ & A set of all ports, $V=N \cup\left\{\nu_{1}, \cdots, \nu_{n}\right\} \cup\left\{\nu_{1}^{\prime}, \cdots, \nu_{n}^{\prime}\right\}$ in the graph $G=\{V, A\}$ \\
$A$ & A set of all routes, $A=V \times V$ in the graph $G=\{V, A\}$ \\
\hline
\end{tabular}

\section{Parameters}

\begin{tabular}{|c|c|}
\hline Symbol & Meaning \\
\hline$i$ & $\begin{array}{l}\text { The existing load in the } i \text { th port. Each load has two ports: the loading port }(i) \text { and discharge } \\
\text { port }(n+1)\end{array}$ \\
\hline$V_{k}$ & Any $k$ ship can move under the graph $G_{k}=\left\{V_{k}, A_{k}\right\}$ so that $V_{k}=N \cup\left\{\nu_{k}\right\} \cup\left\{\nu_{k}^{\prime}\right\}$ \\
\hline$A_{k}$ & Any $k$ ship can move under the graph $G_{k}=\left\{V_{k}, A_{k}\right\}$ so that $V_{k}=N \cup\left\{\nu_{k}\right\} \cup\left\{\nu_{k}^{\prime}\right\}$ \\
\hline$T_{i j k}$ & Travel time from port $i$ to port $j$ by ship $k$ \\
\hline$C_{i j k}$ & $\begin{array}{l}\text { The cost of travel from the port } i \text { to port } j \text { by ship } k \text { (including the fixed cost of port } j \text { and } \\
\text { travel cost) }\end{array}$ \\
\hline$L_{i}$ & $\begin{array}{l}\text { The amount of loaded or unloaded cargo in port } i \text { if } i \in P . L_{i}=L_{n+i} \text { if } i \in P \text { and } n+i \in D \\
\text { indicating that the amount of loading in port } i \text { is equal to the amount of unloading in port } n+i\end{array}$ \\
\hline$S_{i}$ & The time tasks to anchor in port $i$ \\
\hline$H_{k}$ & Maximum capacity of ship $k$ \\
\hline$E_{i}$ & The earliest arrival acceptable time in the time window for the port $i \in V$ \\
\hline$F_{i}$ & The latest arrival acceptable time in the time window for the port $i \in V$ \\
\hline$C_{b k}^{w}$ & The cost of selecting dock $b$ as the departure of the ship $k$ \\
\hline$C_{b k}^{w^{\prime}}$ & The cost of selecting dock $b$ as the destination of the ship $k$ \\
\hline$R_{i}$ & Freight cost of tramps for shipment of cargo $i$ which is proportional to the amount of the cargo \\
\hline \multicolumn{2}{|r|}{ Decision variables } \\
\hline Symbol & Meaning \\
\hline$x_{i j k}$ & 1 , if the ship passes through the arc $(i, j), 0$ otherwise \\
\hline$q_{i k}$ & The amount of cargo in the ship $k$ when it arrives at port $i$ \\
\hline$a_{i k}$ & Time to reach port $I$ by ship $k$ \\
\hline$y_{i k}$ & A portion of the cargo in port $i$ serviced by the ship (by liners) \\
\hline$Z_{i}$ & A portion of the cargo in port $i$ that is serviced by tramp vessels \\
\hline$\nu_{k}$ & The departure condition of ship $k, \nu_{k}=2 n+k$ \\
\hline$\nu_{k}^{\prime}$ & The destination condition of ship $k, \nu_{k}^{\prime}=2 n+h+k$ \\
\hline$w_{b k}$ & 1 if dock $b$ is the departure of the ship $k, 0$ otherwise \\
\hline$w_{b k}^{\prime}$ & 1 if dock $b$ is the destination of the ship $k, 0$ otherwise \\
\hline
\end{tabular}




$$
\begin{aligned}
\min \sum_{k \in K} \sum_{(i, j) \in A} C_{i j k} x_{i j k}+\sum_{i \in P} R_{i} L_{i} Z_{i} \\
\quad+\sum_{b \in E} \sum_{k \in K} C_{b k}^{w} W_{b k}+\sum_{b \in E} \sum_{k \in K} C_{b k}^{w^{\prime}} W_{b k}^{\prime}
\end{aligned}
$$

s.t.:

$\sum_{k \in K} Y_{i k}+Z_{i}=1 \quad \forall i \in P$

$$
\sum_{j \in V} x_{m j k}-\sum_{i \in V} x_{i, n+m, k}=0
$$

$$
\forall k \in K, \quad \forall m \in P,
$$

$\sum_{j \in P} x_{b j k}=W_{b k} \quad \forall k \in K, \quad \forall b \in E$,

$\sum_{i \in D} x_{i b k}=W_{b k}^{\prime} \quad \forall k \in K, \quad \forall b \in E$,

$$
\sum_{b \in E} W_{b k} \leq 1 \quad \forall k \in K
$$

$$
\sum_{b \in E} W_{b k}^{\prime} \leq 1 \quad \forall k \in K
$$

$\sum_{i \in V} x_{i m k}-\sum_{j \in V} x_{m j k}=0 \quad \forall k \in K, \quad \forall m \in P \cup D$,

$Y_{i, k}+Y_{n+i, k}=0 \quad \forall k \in K, \quad \forall i \in P$

$$
Y_{j k} \leq \sum_{i \in V} x_{i j k} \quad \forall k \in K, \quad \forall j \in P,
$$

$$
a_{i k}+S_{i}+T_{i j k} \leq a_{j k}+M\left(1-x_{i j k}\right)
$$

$$
\forall k \in K, \quad \forall i \in V, \quad j \in P \cup D,
$$

$$
E_{i} \leq a_{i k} \leq F_{i} \quad \forall k \in K, \quad \forall i \in N,
$$

$$
a_{i k}+T_{i, n+i, k} \leq a_{n+i, k} \quad \forall k \in K, \quad \forall i \in P,
$$

$$
q_{i k}+L_{i} Y_{i k} \leq q_{j k}+M\left(1-x_{i j k}\right)
$$

$$
\forall k \in K, \quad \forall i \in V, \quad j \in P \cup D,
$$

$$
q_{b k} \leq H_{k}\left(1-w_{b k}\right) \quad \forall k \in K, \quad \forall b \in E,
$$$$
q_{i k} \leq H_{k}
$$$$
\forall k \in K, \quad \forall i \in N
$$$$
x_{i j k} \in\{0,1\}
$$$$
\forall k \in K, \quad \forall(i, j) \in A_{k},
$$

$$
\begin{array}{ll}
Z_{i} \geq 0 & \forall i \in P, \\
a_{i k} \geq 0 & \forall k \in K, \quad \forall i \in V_{k}, \\
q_{i k} \geq 0 & \forall k \in K, \quad \forall i \in V_{k}, \\
Y_{i k} \geq 0 & \forall k \in K, \quad \forall i \in P, \\
Y_{n+i, k} \leq 0 & \forall k \in K, \quad \forall i \in P .
\end{array}
$$

In this model, the objective function (1) minimizes the total costs including the cost of servicing by tramps and liners and the cost of selecting the dock as the departure and destination. Constraint (2) indicates that all cargoes are serviced by liners and trampers (every cargo can be serviced by more than one vessel at a time). Constraint (3) relates to the protection of the load from the loading node to the discharge node, which means that if the ship $k$ goes to the port $i$ for loading $i$, it must meet the discharge port $n+1$ for unloading cargo $i$. Constraint (4) implies that if the dock $b$ is the departure of the ship $k$, then the ship $k$ departs from the departure point to one of the loading ports or goes straight to its destination. Constraint (5) indicates that if the dock $b$ is the destination of the ship $k$, then the ship $k$ goes to its destination from one of the discharge ports or goes to the destination directly from its departure. Constraints (6) and (7) ensure that each ship can only have one departure and one destination. Constraint (8) indicates that if the vessel enters one of the middle ports, it must exit that port, too. Constraint (9) ensures that the amount of cargo loaded in port $i$ by the liners is equal to the amount of cargo discharged at the corresponding node. Constraint (10) implies that if the ship $k$ has been loaded in port $j$, it must have met port $j$. Constraint (11) presents that when ship $k$ arrives at port $j$ so that if skip $k$ has passed arc $(i, j) \in A_{k}$, time of reaching ship $k$ to port $j$ is greater than or equal to the arrival time to port $i$ plus the time of anchoring in port $i$ plus the time of moving from $i$ to $j$. Constraint (12) guarantees that the arrival time of the ship does not exceed the window time of port $i$. Constraint (13) indicates that the loading of cargo $i$ by the ship $k$ occurs before its discharge in its corresponding port. Constraint (14) expresses the existing cargo in ship $k$ in port $i$ similar to Constraint (11). Constraint (15) shows that cargo on board ship does not exceed the ship capacity. Constraints (16) to (22) determine the limits of decision variables.

\section{Genetic Algorithm (GA)}

To solve the proposed model as an NP-hard problem, a GA is applied. Nature-inspired optimization methods differ significantly from conventional optimization 
methods [23]. In conventional methods, each new solution candidate is selected as the new solution if it improves the Objective Function Value (OFV); however, in nature-inspired algorithms, all new candidate solutions have the opportunity to be chosen [24].

GA introduced by Holland [5] is one of the most important heuristic algorithms used to optimize different functions. In this algorithm, past information is extracted concerning the hereditary nature of the algorithm and used in the search process.

\subsection{Solution structure display}

The first and most crucial step in implementing a GA is the solution display [25]. The solution structure presented in this problem consists of five rectangular matrices that are given in Figures 2-6 and are described in turn:

The first matrix: This matrix is called $T$ matrix. With this matrix, all possible routes are created ac-

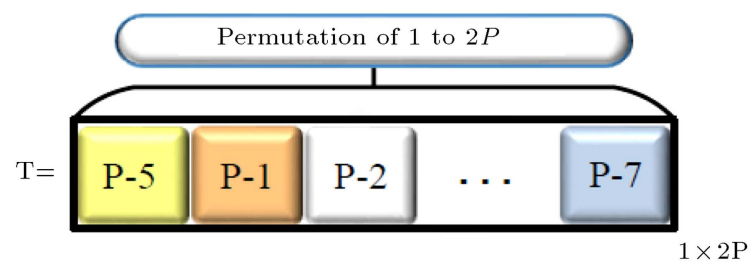

Figure 2. The first chromosome string for establishing the route.

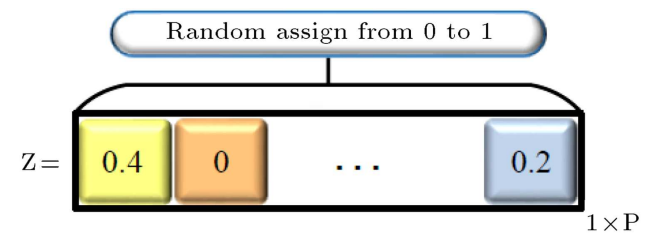

Figure 3. The second chromosome string to determine the ratio of loading of liner and tramp ships.

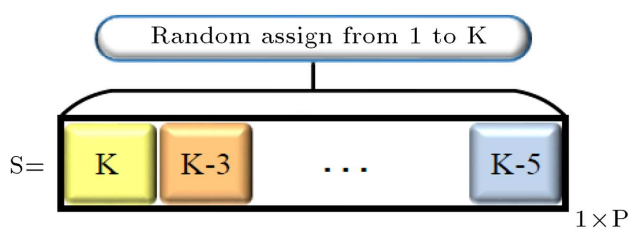

Figure 4. The third chromosome string to allocate loading and discharge ports to liners.

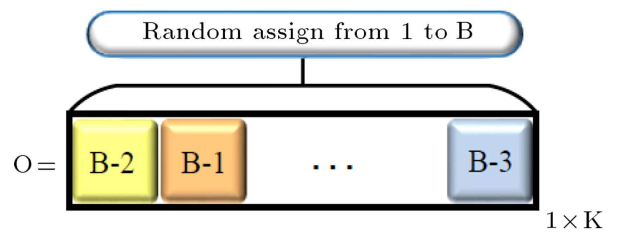

Figure 5. The fourth chromosome string to determine the departure port of the ship.

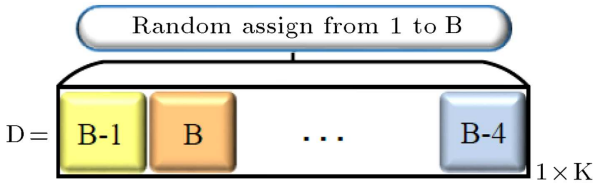

Figure 6. The fifth chromosome string to specify the destination port of the ship.

cording to the problem conditions. The dimension of this matrix is $1 \times 2 P$, and $P$ denotes the number of nodes in which the loading is done and the numbers 1 through $2 P$ are randomly permutated there. Since each loading node has its corresponding discharge node, in some routes, the problem conditions are not met; therefore, unjustified solutions are removed using a heuristic algorithm.

In the heuristic algorithm, each route starts from the initial node and the modified path is generated in the second matrix. If the examined node is the loading port, it is placed at the beginning of the second matrix. However, if the examined node is the discharge node, there are two states. If its corresponding loading port has been serviced, it is added to the continuation of the second matrix; otherwise, it remains in its initial position and the procedure resumes from the beginning of the initial route again.

For example, if there are 5 loading ports and 5 discharge ports and the random path created by the string chromosome $T$, then Eq. (23) is the heuristic algorithm that operates as follows:

$$
8 \rightarrow 9 \rightarrow 1 \rightarrow 2 \rightarrow 7 \rightarrow 3 \rightarrow 5 \rightarrow 10 \rightarrow 4 \rightarrow 6 .
$$

First, nodes 8 and 9 are checked. Since both nodes are discharge nodes and their prerequisites have not been met, they are not transferred to the second matrix. Then, node 1 is transferred to the second matrix since it is a loading node. Each time that a node is moved to the second matrix, the first matrix is checked from the beginning of the route; therefore, after transferring port 1 to the modified matrix, Ports 8 and 9 are re-examined and they remain in their positions because their prerequisites have not been met. In the next step, node 2 is moved to the second matrix and still prerequisites of nodes 8 and 9 have remained unfulfilled. Node 7 is a discharge port and its corresponding loadig port (port 2) has already been serviced; therefore, it is added to the continuation of the modified matrix. Port 3 has no prerequisite and, then, the discharge port 8 is added to the modified matrix because its prerequisite (port 3 ) has been serviced. This process repeats until all ports are transferred to the second matrix. The modified route is as follows:

$$
1 \rightarrow 2 \rightarrow 7 \rightarrow 3 \rightarrow 8 \rightarrow 5 \rightarrow 10 \rightarrow 4 \rightarrow 9 \rightarrow 6 .
$$

The second matrix: This matrix is called $Z$ matrix. This chromosomal string has $1 \times P$ dimensions and 
determines the ratio of loading in each port by liners and trampers. Numbers from 0 to 1 are assigned to each gene of the chromosome. For example, if the first gene has a value of 0.2 , it means that 0.2 of the cargo of the first loading port is serviced by the tramp vessel.

The third matrix: This chromosomal string has $1 \times P$ dimensions and is called $S$ matrix. The genes in this chromosome are numbered 1 to $k$, representing which ship is servicing, what loading port, and its corresponding discharge port. For example, if the problem has 5 loading ports, 5 discharge ports, and 2 liners and the first gene is assigned 2, it means that the loading port 5 and the discharge port 6 are serviced by ship 2 .

The fourth Matrix: This chromosomal string has $1 \times k$ dimensions and is called $\mathrm{O}$. This chromosome determines the origin of the vessels and assigns numbers 1 to $b$ to each gene. For example, if the problem has 3 ports of departure and destination, each gene is assigned numbers 1 to 3 . If the first gene of the chromosome has a value of 2 , it means that the departure of the first vessel is port 2 .

The fifth matrix: This chromosome is named $D$ and acts exactly like the $O$ chromosome, except that it determines the destination of each vessel.

\section{Computational results}

In this section, first, the parameters of the GA algorithm are adjusted; then, some random test problems are generated and the performance of the presented model is investigated by using an exact solver and the GA algorithm.

\subsection{Parameter setting}

The quality of an algorithm is significantly influenced by its parameter values. One of the purposes of the design of the experiments is to change the input variables deliberately to detect and identify the output variations [26]. There are several methods to design the experiment. One of these methods is parameter tuning by the Taguchi method that proposes a minimum number of orthogonal experimental designs in which the factors can be independently verified. In this method, the Signal to Noise ratio $(S / N)$ is used to determine the best combination of experiments. To measure the best $N / S$ ratios, Taguchi has proposed three equations of $(25)-(27)$ in which $Y_{i}$ is the answer value in the $i$ th experimental condition and $\mathrm{n}$ is the number of designed experiments. Also, in the equations, $S$ and $y$ are the mean and variance of the experiment answers, respectively [27].

$$
\begin{aligned}
& (S / N)_{S}=-10 \log _{10}\left(\frac{\sum y_{i}^{2}}{n}\right), \\
& (S / N)_{t}=-10 \log _{10}\left(\frac{1}{n} \sum \frac{1}{y_{i}^{2}}\right), \\
& (S / N)_{T}=-10 \log _{10}\left(\frac{y^{2}}{s^{2}}\right) .
\end{aligned}
$$

To improve the performance of the proposed algorithms, we adjusted their input parameters by the Taguchi method. Because of the designed problems for the model, the parameter setting has been applied to Problem 20. Table 2 presents different levels of the parameters of the GA. The experiments are for algorithm $L_{9}$ using the Taguchi method. Table 3 presents the orthogonal arrays of the algorithm and its results.

Table 2. Parameter levels of Genetic Algorithm (GA) algorithm.

\begin{tabular}{cccc} 
Parameters & Low (1) & Medium (2) & High (3) \\
\hline npop & 50 & 100 & 150 \\
$n I t$ & 50 & 100 & 150 \\
$P c$ & 0.5 & 0.7 & 0.9 \\
$P m$ & 0.3 & 0.4 & 0.5 \\
\hline
\end{tabular}

Table 3. The designed experiments of Genetic Algorithm (GA) algorithm.

\begin{tabular}{cccccc}
\hline прор & nImp & max $i t$ & bata & $\boldsymbol{R P D}$ & $\boldsymbol{S} / \boldsymbol{N}$ \\
\hline 1 & 1 & 1 & 1 & 0.0250673 & 12.01784 \\
1 & 2 & 2 & 2 & 0.116317 & 18.68716 \\
1 & 3 & 3 & 3 & 0.107701 & 19.35564 \\
2 & 1 & 2 & 3 & 0.078352 & 22.11898 \\
2 & 2 & 3 & 1 & 0.116317 & 18.68716 \\
2 & 3 & 1 & 2 & 0.063274 & 23.97548 \\
3 & 1 & 3 & 2 & 0 & 80 \\
3 & 2 & 1 & 3 & 0.094238 & 20.51548 \\
3 & 3 & 2 & 1 & 0 & 80 \\
\hline
\end{tabular}




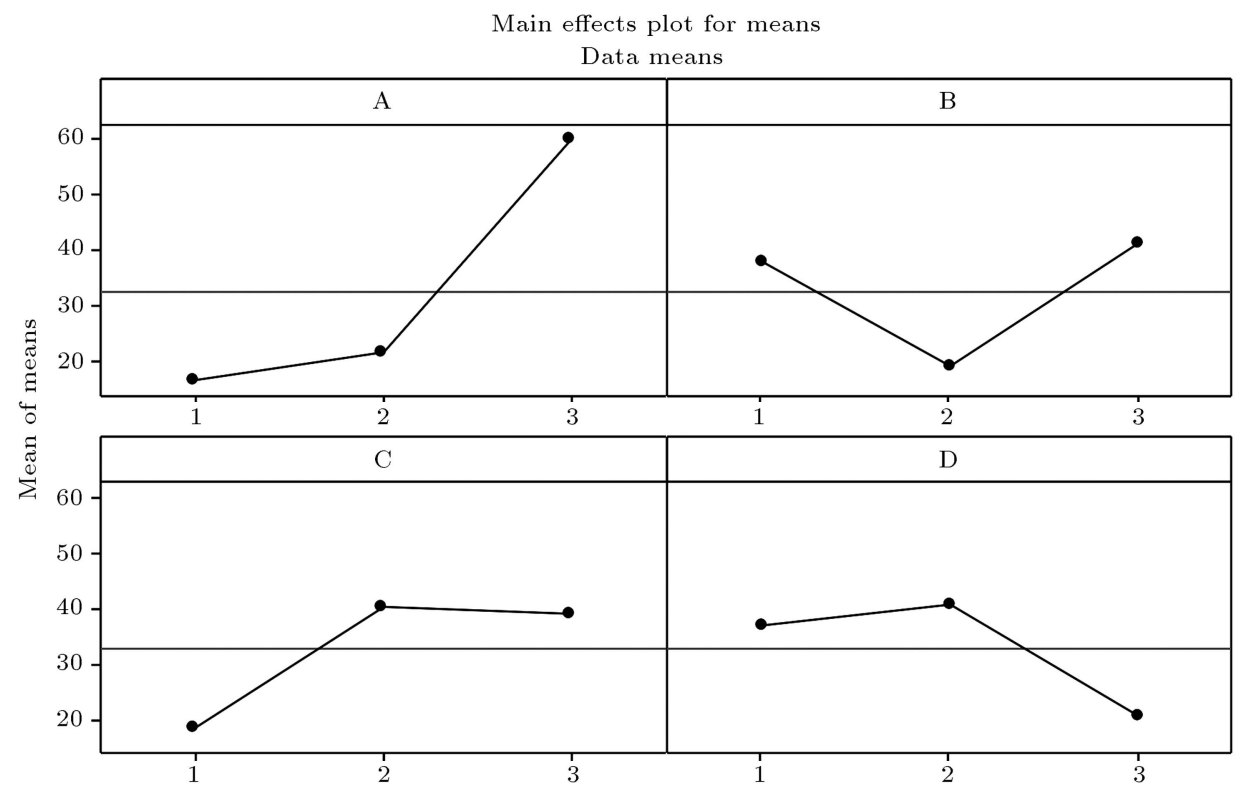

Figure 7. $S / N$ diagram of Genetic Algorithm (GA).

Table 4. The optimal values of parameters of FA and ICA algorithms.

\begin{tabular}{ccccc}
\hline \multirow{2}{*}{ Algorithm } & \multicolumn{5}{c}{ Optimal value } \\
\cline { 2 - 5 } & npop & nIt & PC & PM \\
\hline ICA & 150 & 150 & 0.7 & 0.4 \\
\hline
\end{tabular}

The $S / N$ index obtained for each algorithm parameter in Figure 7 indicates the best level for the algorithm. The optimum values for each parameter are also shown in Table 4.

\subsection{Random example in small and large scales} In this section, the performance of the presented routing model and the GA algorithm extension is verified through 10 numerical examples on a small scale and 10 numerical examples on a large scale. Tables A.1 and A.2 in the Appendix illustrate the parameters of the examples generated on small and large scales. Smallscale examples are optimally solved by exact solver in LINGO 17.0 software using a $3.5 \mathrm{GHz} \mathrm{PC}$ and 8 GB RAM. Also, all examples have been solved by the introduced GA algorithm in MATLAB. Then, the results of the $\mathrm{B} \& \mathrm{~B}$ and $\mathrm{GA}$ methods were compared in terms of the OFV and CPU time. Each example was solved 20 times by the GA algorithm and, then, the average $\mathrm{OFV}$ and $\mathrm{CPU}$ time values were reported. Since differences between the exact method and GA are reasonable, the accuracy of model is proven.

Also, the routes of liners and tramps can be observed under the Rout column in Table 5. Figure 8 shows the graphical representation of the solution problem. In this problem, we have considered 8 loading ports (ports 1 to 8 ), 8 discharge ports corresponding to the loading ports (ports 9 to 16), and 2 ports for the

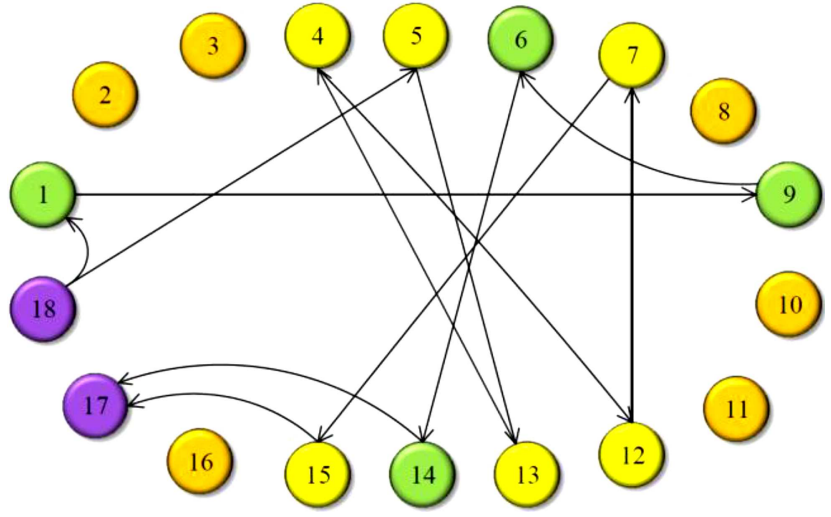

Figure 8. Graphical display of the problem.

ship's departure and destination (17 and 18). There are also 4 liner ships. The first and second ships had no movements. The third ship has met and been serviced by the yellow port, and the fourth ship has visited and serviced the orange ports. Ports 2, 3, 8, 10, 11, and 16 have been serviced by tramp ships. Besides, ports 17 and 18 are the departure and destination of the ships.

\section{Conclusion}

Conventionally, the Vehicle Routing Problem (VRP) is one of well-established and important topics in supply chain and logistic networks. The location-routing decision-making has a significant role to optimize the traveling cost per distance, total traveling time, and the number of vehicles in the supply chain networks most practically for container terminals in the global trade centers. The new contributions of this model were to consider the routes of two types of ships, the time windows, and a multi-modal transportation 
Table 5. The calculation results of numerical examples on small and large scales.

\begin{tabular}{|c|c|c|c|c|c|c|c|}
\hline \multirow[b]{2}{*}{ No. } & \multicolumn{3}{|l|}{ Exact } & \multicolumn{3}{|l|}{ GA } & \multirow[b]{2}{*}{ Gap } \\
\hline & Rout & OFV & $\begin{array}{l}\text { CPU } \\
\text { time } \\
(s)\end{array}$ & Rout & OFV & $\begin{array}{c}\text { Mean } \\
\text { CPU } \\
\text { time } \\
(\mathrm{s})\end{array}$ & \\
\hline 1 & $\begin{aligned} k 1: & 11 \rightarrow 1 \rightarrow 6 \rightarrow 4 \rightarrow 2 \rightarrow 9 \rightarrow 3 \\
& \rightarrow 7 \rightarrow 8 \rightarrow 5 \rightarrow 10 \rightarrow 11\end{aligned}$ & 47 & 1123 & $\begin{aligned} k 1: & 11 \rightarrow 1 \rightarrow 6 \rightarrow 4 \rightarrow 2 \rightarrow 9 \rightarrow 3 \rightarrow 7 \rightarrow 8 \\
& \rightarrow 5 \rightarrow 10 \rightarrow 11\end{aligned}$ & 47 & 4.7 & 0 \\
\hline 2 & $\begin{array}{l}k 2: 8 \rightarrow 1 \rightarrow 4 \rightarrow 3 \rightarrow 2 \rightarrow 6 \rightarrow 5 \rightarrow 7 \\
k 3: 8 \rightarrow 3 \rightarrow 6 \rightarrow 8\end{array}$ & 55 & 264 & $\begin{array}{l}k 2: \quad 8 \rightarrow 1 \rightarrow 4 \rightarrow 7 \\
k 3: \quad 8 \rightarrow 3 \rightarrow 6 \rightarrow 2 \rightarrow 5 \rightarrow 8\end{array}$ & 61 & 3.5 & 0.1 \\
\hline 3 & $\begin{aligned} k 3: & 8 \rightarrow 3 \rightarrow 6 \rightarrow 2 \rightarrow 1 \rightarrow 4 \\
& \rightarrow 5 \rightarrow 7\end{aligned}$ & 34.1 & 2 & $k 3: 8 \rightarrow 3 \rightarrow 6 \rightarrow 2 \rightarrow 1 \rightarrow 4 \rightarrow 5 \rightarrow 7$ & 34.1 & 3.5 & 0 \\
\hline 4 & $\begin{aligned} k 1: & 9 \rightarrow 2 \rightarrow 6 \rightarrow 4 \rightarrow 8 \rightarrow 1 \rightarrow 3 \\
& \rightarrow 5 \rightarrow 7 \rightarrow 10\end{aligned}$ & 47.03 & 52 & $k 2: 9 \rightarrow 4 \rightarrow 8 \rightarrow 1 \rightarrow 2 \rightarrow 5 \rightarrow 6 \rightarrow 10$ & 50.67 & 3 & 0.07 \\
\hline 5 & $\begin{array}{l}k 1: 9 \rightarrow 1 \rightarrow 3 \rightarrow 5 \rightarrow 7 \rightarrow 10 \\
\text { Tramp ship: } 2,4,6,8\end{array}$ & 30.98 & 20 & $\begin{array}{l}k 2: 9 \rightarrow 1 \rightarrow 5 \rightarrow 3 \rightarrow 7 \rightarrow 10 \\
\text { Tramp ship: } 2,4,6,8\end{array}$ & 36.78 & 3 & 0.18 \\
\hline 6 & 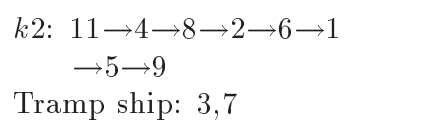 & 33.57 & 16 & $\begin{array}{l}k 2: 9 \rightarrow 4 \rightarrow 8 \rightarrow 2 \rightarrow 6 \rightarrow 1 \rightarrow 5 \rightarrow 9 \\
\text { Tramp ship: } 3,7\end{array}$ & 33.57 & 4 & 0 \\
\hline 7 & $\begin{aligned} k 1: & 9 \rightarrow 2 \rightarrow 4 \rightarrow 8 \rightarrow 3 \rightarrow 7 \\
& \rightarrow 6 \rightarrow 1 \rightarrow 5 \rightarrow 10\end{aligned}$ & 45.16 & 267 & $\begin{aligned} k 1: & 9 \rightarrow 2 \rightarrow 4 \rightarrow 8 \rightarrow 3 \rightarrow 7 \rightarrow 6 \rightarrow 1 \\
& \rightarrow 5 \rightarrow 10\end{aligned}$ & 45.16 & 4.2 & 0 \\
\hline 8 & $\begin{aligned} k 1: & 11 \rightarrow 1 \rightarrow 6 \rightarrow 3 \rightarrow 8 \rightarrow 4 \rightarrow 9 \\
& \rightarrow 5 \rightarrow 10 \rightarrow 2 \rightarrow 7 \rightarrow 13\end{aligned}$ & 38 & 2521 & 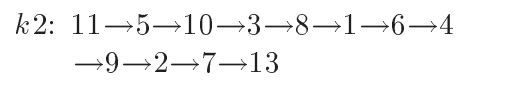 & 39 & 5 & 0.02 \\
\hline 9 & 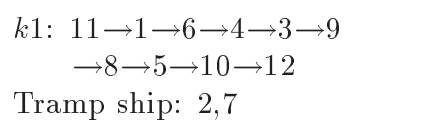 & 38.36 & 87 & $\begin{array}{l}k 1: 11 \rightarrow 1 \rightarrow 6 \rightarrow 5 \rightarrow 10 \rightarrow 12 \\
\text { Tramp ship: } 2,3,4,7,8,9\end{array}$ & 39.96 & 4 & 0.04 \\
\hline 10 & $\begin{array}{l}k 1: 15 \rightarrow 5 \rightarrow 11 \rightarrow 2 \rightarrow 8 \rightarrow 15 \\
\text { Tramp ship: } 1,3,4,6,7,9,10,12\end{array}$ & 44.6 & 414 & $\begin{array}{l}k 1: 15 \rightarrow 5 \rightarrow 11 \rightarrow 2 \rightarrow 8 \rightarrow 15 \\
\text { Tramp ship: } 1,3,4,6,7,9,10,12\end{array}$ & 44.6 & 3.6 & 0 \\
\hline 11 & - & - & $\begin{array}{l}\text { More than } \\
\text { one hour }\end{array}$ & $\begin{array}{l}k 2: \quad 15 \rightarrow 5 \rightarrow 11 \rightarrow 14 \\
k 3: \quad 13 \rightarrow 4 \rightarrow 10 \rightarrow 2 \rightarrow 8 \rightarrow 14 \\
\text { Tramp ship: } 1,3,6,7,9,12\end{array}$ & 78.66 & 5 & - \\
\hline 12 & - & - & $\begin{array}{l}\text { More than } \\
\text { one hour }\end{array}$ & $\begin{array}{l}k 2: \quad 15 \rightarrow 1 \rightarrow 8 \rightarrow 4 \rightarrow 11 \rightarrow 7 \rightarrow 14 \rightarrow 5 \\
\quad \rightarrow 12 \rightarrow 15 \\
\text { Tramp ship: } 2,3,6,9,10,13\end{array}$ & 51.56 & 4.5 & - \\
\hline 13 & - & - & $\begin{array}{l}\text { More than } \\
\text { one hour }\end{array}$ & $\begin{array}{l}k 2: 15 \rightarrow 2 \rightarrow 9 \rightarrow 6 \rightarrow 13 \rightarrow 15 \\
\text { Tramp ship: } 1,3,4,5,7,8,10,11,12,14\end{array}$ & 89.7 & 4 & - \\
\hline 14 & - & - & $\begin{array}{l}\text { More than } \\
\text { one hour }\end{array}$ & $\begin{array}{l}k 2: \quad 15 \rightarrow 4 \rightarrow 11 \rightarrow 5 \rightarrow 12 \rightarrow 7 \rightarrow 14 \rightarrow 15 \\
\text { Tramp ship: } 1,2,3,6,8,9,10,13\end{array}$ & 94.8 & 5 & - \\
\hline 15 & - & - & $\begin{array}{l}\text { More than } \\
\text { one hour }\end{array}$ & $\begin{array}{l}k 2: \quad 17 \rightarrow 7 \rightarrow 15 \rightarrow 8 \rightarrow 16 \rightarrow 6 \rightarrow 14 \rightarrow 5 \\
\quad \rightarrow 13 \rightarrow 1 \rightarrow 9 \rightarrow 18 \\
\text { Tramp ship: } 2,3,4,10,11,12\end{array}$ & 64.96 & 6 & - \\
\hline 16 & - & - & $\begin{array}{l}\text { More than } \\
\text { one hour }\end{array}$ & $\begin{array}{l}k 2: \quad 17 \rightarrow 5 \rightarrow 13 \rightarrow 7 \rightarrow 15 \rightarrow 6 \rightarrow 14 \rightarrow 2 \\
\quad \rightarrow 10 \rightarrow 1 \rightarrow 9 \rightarrow 18 \\
\text { Tramp ship: } 3,4,8,11,12,16\end{array}$ & 70.44 & 6 & - \\
\hline
\end{tabular}


Table 5. The calculation results of numerical examples on small and large scales (continued).

\begin{tabular}{|c|c|c|c|c|c|c|c|}
\hline \multirow[b]{2}{*}{ No. } & \multicolumn{3}{|c|}{ Exact } & \multicolumn{3}{|l|}{ GA } & \multirow[b]{2}{*}{ Gap } \\
\hline & Rout & OFV & $\begin{array}{l}\text { CPU } \\
\text { time } \\
(\mathrm{s})\end{array}$ & Rout & OFV & $\begin{array}{c}\text { Mean } \\
\text { CPU } \\
\text { time } \\
(\mathrm{s})\end{array}$ & \\
\hline 17 & - & - & $\begin{array}{l}\text { More than } \\
\text { one hour }\end{array}$ & $\begin{array}{l}k 1: \quad 18 \rightarrow 4 \rightarrow 12 \rightarrow 5 \rightarrow 13 \rightarrow 7 \rightarrow 15 \rightarrow 6 \rightarrow 14 \rightarrow 18 \\
\text { Tramp ship: } 1,2,3,8,9,10,11,16\end{array}$ & 89.26 & 5 & - \\
\hline 18 & - & - & $\begin{array}{l}\text { More than } \\
\text { one hour }\end{array}$ & $\begin{array}{l}k 3: \quad 18 \rightarrow 5 \rightarrow 13 \rightarrow 4 \rightarrow 12 \rightarrow 7 \rightarrow 15 \rightarrow 17 \\
k 4: \quad 18 \rightarrow 1 \rightarrow 9 \rightarrow 6 \rightarrow 14 \rightarrow 17 \\
\text { Tramp ship: } 2,3,8,10,11,16\end{array}$ & 70.26 & 5.5 & - \\
\hline 19 & - & - & $\begin{array}{l}\text { More than } \\
\text { one hour }\end{array}$ & $\begin{array}{l}k 1: \quad 19 \rightarrow 6 \rightarrow 15 \rightarrow 8 \rightarrow 17 \rightarrow 1 \rightarrow 10 \rightarrow 9 \rightarrow 18 \rightarrow 19 \\
k 2: \quad 19 \rightarrow 5 \rightarrow 14 \rightarrow 7 \rightarrow 16 \rightarrow 4 \rightarrow 13 \rightarrow 20 \\
\text { Tramp ship: } 2,3,11,12\end{array}$ & 66.46 & 6.5 & - \\
\hline 20 & - & - & $\begin{array}{c}\text { More than } \\
\text { one hour }\end{array}$ & $\begin{array}{l}k 3: \quad 14 \rightarrow 5 \rightarrow 11 \rightarrow 13 \\
k 4: \quad 14 \rightarrow 1 \rightarrow 7 \rightarrow 4 \rightarrow 10 \rightarrow 14 \\
k 5: \quad 14 \rightarrow 6 \rightarrow 12 \rightarrow 14 \\
\text { Tramp ship: } 2,3,8,9,13,14\end{array}$ & 39.46 & 5 & - \\
\hline
\end{tabular}

system simultaneously. The proposed was solved by an exact solver as well as a Genetic Algorithm (GA) for large-scale tests. The performance of GA was enhanced by a Taguchi experimental design method. Finally, an in-depth analysis and discussion were provided.

This research can open several new contributions for the future works. No doubt other heuristics and metaheuristics can solve the proposed problem practically and computationally better than GA. Therefore, more efforts to solve heuristically the proposed problem are needed. The sustainability dimensions and environmental protections can be ordered to improve the proposed modeling by a multi-objective optimization as a potential continuation of this paper.

\section{References}

1. Dantzig, G.B. and Ramser, J.H. "The truck dispatching problem", Management Science, 6(1), pp. 80-91 (1959).

2. Clarke, G. and Wright, J.W. "Scheduling of vehicles from a central depot to a number of delivery points", Operations Research, 12(4), pp. 568-581 (1964).

3. Toth, P. and Vigo, D., Eds., The Vehicle Routing Problem, Society for Industrial and Applied Mathematics, (2001).

4. Nasiri, M.M., Rahbari, A., Werner, F., and Karimi, R. "Incorporating supplier selection and order allocation into the vehicle routing and multi-cross-dock schedul- 
ing problem", International Journal of Production Research, 56(19), pp. 6527-6552 (2018).

5. Fathollahi-Fard, A.M., Govindan, K., HajiaghaeiKeshteli, M., and Ahmadi, A. "A green home health care supply chain: New modified simulated annealing algorithms", Journal of Cleaner Production, 240, 118200 (2019).

6. Coelho, V.N., Grasas, A., Ramalhinho, H., Coelho, I.M., Souza, M.J.F., and Cruz, R.C. "An ILS-based algorithm to solve a large-scale real heterogeneous fleet VRP with multi-trips and docking constraints", European Journal of Operational Research, 250(2), pp. 367-376 (2016).

7. Perera, L.P. and Soares, C.G. "Weather routing and safe ship handling in the future of shipping", Ocean Engineering, 130, pp. 684-695 (2017).

8. Li, F., Golden, B., and Wasil, E. "The open vehicle routing problem: Algorithms, large-scale test problems, and computational results", Computers \& Operations Research, 34(10), pp. 2918-2930 (2010).

9. Daganzo, C.F. "The crane scheduling problem", Transportation Research Part B: Methodological, 23(3), pp. 159-175 (1989).

10. Zhihong, J.I.N. and Na, L.I. "Optimization of quay crane dynamic scheduling based on berth schedules in container terminal", Journal of Transportation Systems Engineering and Information Technology, 11(3), pp. 58-64 (2011).

11. Chen, J.H., Lee, D.H., and Cao, J.X. "Heuristics for quay crane scheduling at indented berth", Transportation Research Part E: Logistics and Transportation Review, 47(6), pp. 1005-1020 (2011).

12. Legato, P., Trunfio, R., and Meisel, F. "Modeling and solving rich quay crane scheduling problems", Computers \& Operations Research, 39(9), pp. 20632078 (2012).

13. Chen, J.H., Lee, D.H., and Goh, M. "An effective mathematical formulation for the unidirectional cluster-based quay crane scheduling problem", European Journal of Operational Research, 232(1), pp. 198-208 (2014).

14. Imai, A., Yamakawa, Y., and Huang, K. "The strategic berth template problem", Transportation Research Part E: Logistics and Transportation Review, 72, pp. 77-100 (2014).

15. Al-Dhaheri, N. and Diabat, A. "The quay crane scheduling problem", Journal of Manufacturing Systems, 36, pp. 87-94 (2015).

16. Al-Dhaheri, N., Jebali, A., and Diabat, A. "The quay crane scheduling problem with nonzero crane repositioning time and vessel stability constraints", Computers \& Industrial Engineering, 94, pp. 230-244 (2016).

17. Liu, C., Zheng, L., and Zhang, C. "Behavior perception-based disruption models for berth allocation and quay crane assignment problems", Computers \& Industrial Engineering, 97, pp. 258-275 (2016).
18. Wu, L. and Ma, W. "Quay crane scheduling with draft and trim constraints", Transportation Research Part E: Logistics and Transportation Review, 97, pp. 38-68 (2017).

19. Agra, A. and Oliveira, M. "MIP approaches for the integrated berth allocation and quay crane assignment and scheduling problem", European Journal of Operational Research, 264(1), pp. 138-148 (2018).

20. Azevedo, A.T., de Salles Neto, L.L., Chaves, A.A., and Moretti, A.C. "Solving the 3D stowage planning problem integrated with the quay crane scheduling problem by representation by rules and genetic algorithm", Applied Soft Computing, 65, pp. 495-516 (2018).

21. Liang, C., Fan, L., Xu, D., Ding, Y., and Gen, M. "Research on coupling scheduling of quay crane dispatch and configuration in the container terminal", Computers \& Industrial Engineering, 125, pp. 649-657 (2018).

22. Safaeian, M., Etebari, F., and Vahdani, B. "An integrated quay crane assignment and scheduling problem with several contractors in container terminals", Scientia Iranica, 28(2), pp. 1030-1048 (2021).

23. Fathollahi-Fard, A.M., Ranjbar-Bourani, M., Cheikhrouhou, N., and Hajiaghaei-Keshteli, M. "Novel modifications of social engineering optimizer to solve a truck scheduling problem in a cross-docking system", Computers \& Industrial Engineering, 137, 106103 (2019).

24. Fatehi-Kivi, A., Mehdizadeh, E., and TavakkoliMoghaddam, R. "A new mathematical model for a multi-product supply chain network with a preventive maintenance policy", International Journal of Engineering, 32(10), pp. 1446-1453 (2019).

25. Fathollahi-Fard, A.M., Hajiaghaei-Keshteli, M., and Tavakkoli-Moghaddam, R. "A Lagrangian relaxationbased algorithm to solve a home health care routing problem", International Journal of Engineering, 31(10), pp. 1734-1740 (2018).

26. Mohammadzadeh, H., Sahebjamnia, N., FathollahiFard, A M., and Hahiaghaei-Keshteli, M. "New Approaches in metaheuristics to solve the truck scheduling problem in a cross-docking center", International Journal of Engineering-Transactions B: Applications, 31(8), pp. 1258-1266 (2018).

27. Liu, X., Tian, G., Fathollahi-Fard, A.M., and Mojtahedi, M. "Evaluation of ship's green degree using a novel hybrid approach combining group fuzzy entropy and cloud technique for the order of preference by similarity to the ideal solution theory", Clean Technologies and Environmental Policy, 22(2), pp. 493-512 (2020).

\section{Appendix A}

Parameters of the examples generated on small and large scales are shown in Tables A.1 and A.2. 
Table A.1. Parameters of random instances in small and big sizes.

\begin{tabular}{|c|c|c|c|c|c|c|c|c|c|c|c|c|}
\hline \multirow{2}{*}{ No. } & \multicolumn{12}{|c|}{ Problem Information } \\
\hline & $P$ & $D$ & $E$ & $k$ & $T_{i j k}$ & $C_{i j k}$ & $R_{i}$ & $S_{i}$ & $E_{i}$ & $F_{i}$ & $\boldsymbol{H}_{k}$ & $L_{i}$ \\
\hline 1 & $1-5$ & $6-10$ & 3 & 2 & $\operatorname{Randi}(0,10)$ & $\operatorname{Randi}(0,10)$ & {$[100,200]$} & $\operatorname{Randi}(1,5)$ & 0 & 100 & 1000 & Randi $(50,100)$ \\
\hline 2 & $1-3$ & $4-6$ & 2 & 3 & $\operatorname{Randi}(0,10)$ & $\operatorname{Randi}(0,10)$ & {$[13,20]$} & $\operatorname{Randi}(1,5)$ & 0 & $\operatorname{Randi}(20,30)$ & $(120,110,130)$ & $\operatorname{Randi}(80,130)$ \\
\hline 3 & $1-3$ & $4-6$ & 3 & 3 & $\operatorname{Randi}(0,10)$ & $\operatorname{Randi}(0,10)$ & {$[0.02,0.9]$} & Randi $(1,5)$ & 0 & $\operatorname{Randi}(30,60)$ & $(80,110,150)$ & Randi $(50,120)$ \\
\hline 4 & $1-4$ & $5-8$ & 2 & 2 & $\operatorname{Randi}(0,10)$ & $\operatorname{Randi}(0,10)$ & {$[0.01,0.5]$} & $\operatorname{Randi}(1,5)$ & 0 & Randi $(80,120)$ & $(80,110)$ & Randi $(70,110)$ \\
\hline 5 & $1-4$ & $5-8$ & 2 & 3 & $\operatorname{Randi}(0,10)$ & $\operatorname{Randi}(0,10)$ & {$[0.01,0.5]$} & $\operatorname{Randi}(1,5)$ & 0 & Randi $(80,130)$ & $(80,130)$ & $\operatorname{Randi}(50,100)$ \\
\hline 6 & $1-4$ & $5-8$ & 3 & 2 & $\operatorname{Randi}(0,10)$ & $\operatorname{Randi}(0,10)$ & {$[0.01,0.3]$} & Randi $(1,6)$ & 0 & Randi $(80,130)$ & $(130,140)$ & Randi $(70,120)$ \\
\hline 7 & $1-4$ & $5-8$ & 3 & 3 & $\operatorname{Randi}(0,10)$ & $\operatorname{Randi}(0,10)$ & {$[0.15,0.2]$} & $\operatorname{Randi}(1,5)$ & 0 & Randi $(80,130)$ & $(130,100,110)$ & Randi $(100,120)$ \\
\hline 8 & $1-5$ & $6-10$ & 3 & 3 & $\operatorname{Randi}(0,10)$ & $\operatorname{Randi}(0,10)$ & {$[0.35,0.6]$} & Randi $(1,5)$ & 0 & $\operatorname{Randi}(100,110)$ & $(150,200,100)$ & $\operatorname{Randi}(80,110)$ \\
\hline 9 & $1-5$ & $6-10$ & 3 & 2 & $\operatorname{Randi}(0,10)$ & $\operatorname{Randi}(0,10)$ & {$[0.02,0.2]$} & Randi $(1,5)$ & 0 & $\operatorname{Randi}(100,110)$ & $(100,100)$ & Randi $(80,120)$ \\
\hline 10 & $1-6$ & $7-12$ & 3 & 2 & $\operatorname{Randi}(0,10)$ & $\operatorname{Randi}(0,10)$ & {$[0.01,0.6]$} & $\operatorname{Randi}(1,5)$ & 0 & $\operatorname{Randi}(20,60)$ & $(80,120)$ & $\operatorname{Randi}(70,130)$ \\
\hline 11 & $1-5$ & $6-10$ & 3 & 3 & $\operatorname{Randi}(0,10)$ & $\operatorname{Randi}(0,10)$ & {$[0,0.6]$} & $\operatorname{Randi}(1,5)$ & 0 & $\operatorname{Randi}(20,60)$ & $(80,120)$ & Randi $(70,120)$ \\
\hline 12 & $1-7$ & $8-14$ & 2 & 2 & $\operatorname{Randi}(0,10)$ & $\operatorname{Randi}(0,10)$ & {$[0.01,0.5]$} & $\operatorname{Randi}(1,5)$ & 0 & $\operatorname{Randi}(100,110)$ & $(80,130)$ & Randi $(70,130)$ \\
\hline 13 & $1-7$ & $8-14$ & 3 & 2 & $\operatorname{Randi}(0,10)$ & $\operatorname{Randi}(0,10)$ & {$[0.01,0.5]$} & $\operatorname{Randi}(1,5)$ & 0 & $\operatorname{Randi}(30,70)$ & $(70,100)$ & $\operatorname{Randi}(80,150)$ \\
\hline 14 & $1-7$ & $8-14$ & 2 & 3 & $\operatorname{Randi}(0,10)$ & $\operatorname{Randi}(0,10)$ & {$[0.01,0.9]$} & $\operatorname{Randi}(1,5)$ & 0 & $\operatorname{Randi}(40,80)$ & $(100,130)$ & Randi $(80,140)$ \\
\hline 15 & $1-8$ & $9-16$ & 2 & 3 & $\operatorname{Randi}(0,10)$ & $\operatorname{Randi}(0,10)$ & {$[0.03,0.9]$} & $\operatorname{Randi}(1,5)$ & 0 & Randi $(90,110)$ & $(100,100)$ & $\operatorname{Randi}(80,120)$ \\
\hline 16 & $1-8$ & $9-16$ & 3 & 3 & $\operatorname{Randi}(0,10)$ & $\operatorname{Randi}(0,10)$ & {$[0.01,0.5]$} & $\operatorname{Randi}(1,5)$ & 0 & $\operatorname{Randi}(100,120)$ & $(100,100)$ & $\operatorname{Randi}(80,120)$ \\
\hline 17 & $1-8$ & $9-16$ & 2 & 2 & $\operatorname{Randi}(0,10)$ & $\operatorname{Randi}(0,10)$ & {$[0,0.5]$} & Randi $(1,5)$ & 0 & $\operatorname{Randi}(100,110)$ & $(100,110)$ & Randi $(70,120)$ \\
\hline 18 & $1-8$ & $9-16$ & 2 & 4 & $\operatorname{Randi}(0,10)$ & $\operatorname{Randi}(0,10)$ & {$[0.01,0.5]$} & Randi $(1,5)$ & 0 & $\operatorname{Randi}(100,110)$ & $(100,150)$ & Randi $(100,150)$ \\
\hline 19 & $1-9$ & $10-18$ & 2 & 4 & $\operatorname{Randi}(0,10)$ & $\operatorname{Randi}(0,10)$ & {$[0.01,0.5]$} & $\operatorname{Randi}(1,5)$ & 0 & $\operatorname{Randi}(100,130)$ & $(100,140)$ & Randi $(70,130)$ \\
\hline 20 & $1-6$ & $7-12$ & 2 & 5 & Randi $(0,10)$ & $\operatorname{Randi}(0,10)$ & {$[0.02,0.5]$} & Randi $(1,5)$ & 0 & $\operatorname{Randi}(100,110)$ & $(90,140)$ & Randi $(80,110)$ \\
\hline
\end{tabular}


Table A.2. Parameters of random instances in small and big sizes.

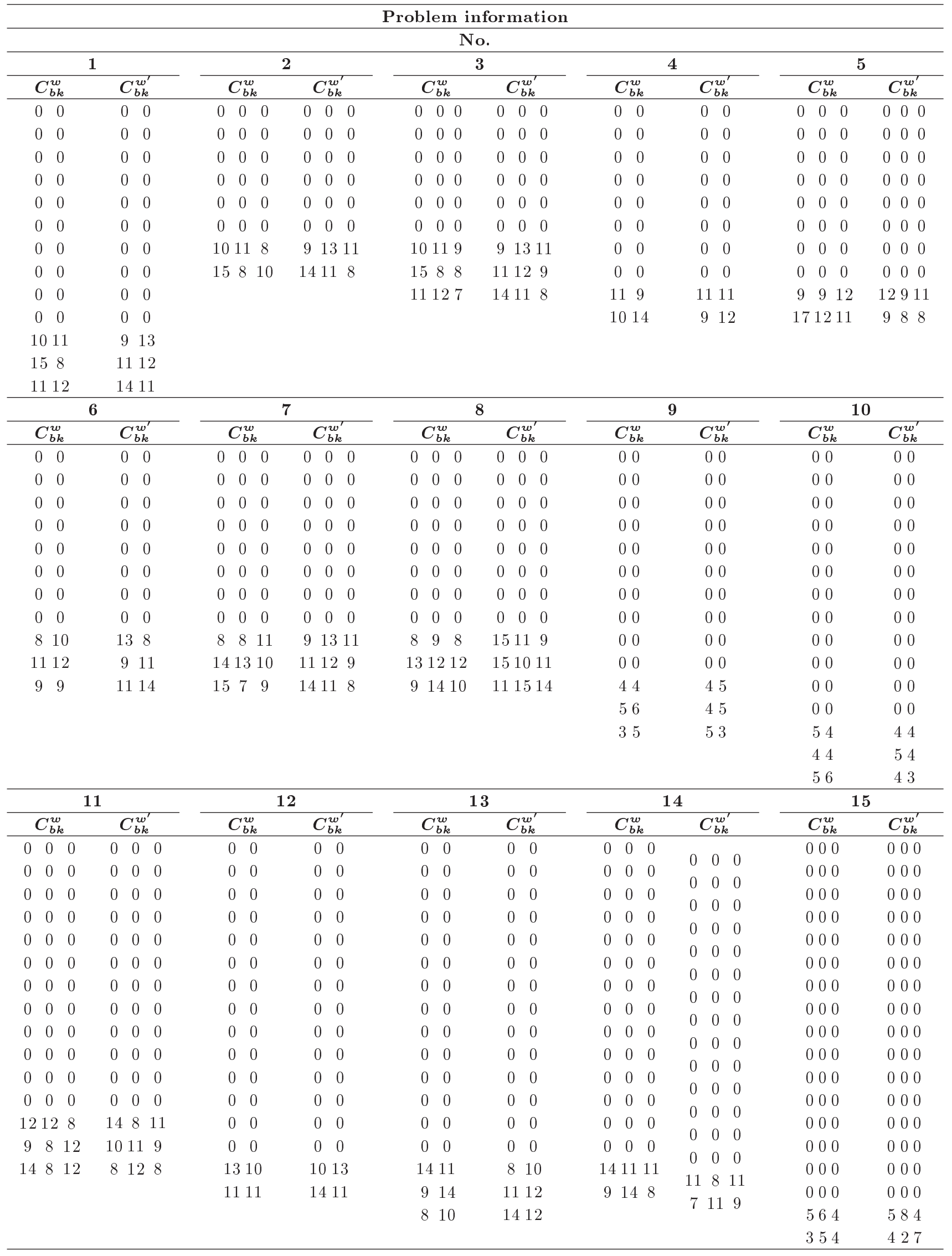


Table A.2. Parameters of random instances in small and big sizes (continued).

\begin{tabular}{|c|c|c|c|c|c|c|c|c|c|}
\hline \multicolumn{10}{|c|}{ Problem information } \\
\hline \multicolumn{10}{|c|}{ No. } \\
\hline \multicolumn{2}{|c|}{16} & \multicolumn{2}{|c|}{17} & \multicolumn{2}{|c|}{18} & \multicolumn{2}{|c|}{19} & \multicolumn{2}{|c|}{20} \\
\hline$C_{b k}^{w}$ & $C_{b k}^{w^{\prime}}$ & $C_{b k}^{w}$ & $C_{b k}^{w^{\prime}}$ & $C_{b k}^{w}$ & $C_{b k}^{w^{\prime}}$ & $C_{b k}^{w}$ & $C_{b k}^{w^{\prime}}$ & $C_{b k}^{w}$ & $C_{b k}^{w^{\prime}}$ \\
\hline $0 \quad 0 \quad 0$ & 000 & 00 & 00 & 0000 & 0000 & 0000 & 0000 & 00000 & 00000 \\
\hline $0 \quad 00$ & 000 & 00 & 00 & 0000 & 0000 & 0000 & 0000 & 00000 & 00000 \\
\hline $0 \quad 0 \quad 0$ & 000 & 00 & 00 & 0000 & 0000 & 0000 & 0000 & 00000 & 00000 \\
\hline $0 \quad 0 \quad 0$ & 000 & 00 & 00 & 0000 & 0000 & 0000 & 0000 & 00000 & 00000 \\
\hline $\begin{array}{lll}0 & 0 & 0\end{array}$ & 000 & 00 & 00 & 0000 & 0000 & 0000 & 0000 & 00000 & 00000 \\
\hline $0 \quad 0 \quad 0$ & 000 & 00 & 00 & 0000 & 0000 & 0000 & 0000 & 00000 & 00000 \\
\hline $\begin{array}{lll}0 & 0 & 0\end{array}$ & 000 & 00 & 00 & 0000 & 0000 & 0000 & 0000 & 00000 & 00000 \\
\hline $\begin{array}{lll}0 & 0 & 0\end{array}$ & 000 & 00 & 00 & 0000 & 0000 & 0000 & 0000 & 00000 & 00000 \\
\hline $\begin{array}{lll}0 & 0 & 0\end{array}$ & 000 & 00 & 00 & 0000 & 0000 & 0000 & 0000 & 00000 & 00000 \\
\hline $\begin{array}{lll}0 & 0 & 0\end{array}$ & 000 & 00 & 00 & 0000 & 0000 & 0000 & 0000 & 00000 & 00000 \\
\hline $\begin{array}{lll}0 & 0 & 0\end{array}$ & 000 & 00 & 00 & 0000 & 0000 & 0000 & 0000 & 00000 & 00000 \\
\hline $\begin{array}{lll}0 & 0 & 0\end{array}$ & 000 & 00 & 00 & 0000 & 0000 & 0000 & 0000 & 00000 & 00000 \\
\hline $\begin{array}{lll}0 & 0 & 0\end{array}$ & 000 & 00 & 00 & 0000 & 0000 & 0000 & 0000 & 85687 & 55937 \\
\hline $\begin{array}{lll}0 & 0 & 0\end{array}$ & 000 & 00 & 00 & 0000 & 0000 & 0000 & 0000 & 61816 & 23156 \\
\hline $\begin{array}{lll}0 & 0 & 0\end{array}$ & 000 & 00 & 00 & 0000 & 0000 & 0000 & 0000 & & \\
\hline $\begin{array}{lll}0 & 0 & 0\end{array}$ & 000 & 00 & 00 & 0000 & 0000 & 0000 & 0000 & & \\
\hline 564 & 584 & 85 & 910 & 1548 & 1936 & 0000 & 0000 & & \\
\hline 354 & 427 & 910 & 45 & 2941 & 2448 & 0000 & 0000 & & \\
\hline \multirow[t]{2}{*}{8104} & 974 & & & & & 1548 & 1936 & & \\
\hline & & & & & & 2941 & 2448 & & \\
\hline
\end{tabular}

\section{Biographies}

Mojgan Safaeian was born in Behbahan, Iran and raised in Tehran, Iran. She earned her BSc degree in Computer Science from Sheikh-Bahaee University, Isfahan, Iran (2010). She also received her MSc degree in Industrial Engineering from Azad University, Qazvin, Iran (2013).

Farhad Etebari received his BS degree in Industrial Engineering from Sharif University of Technology and his MS and $\mathrm{PhD}$ degrees in Industrial Engineering from K.N. Toosi University of Technology. He is currently an Assistant Professor in Industrial Engineering at Azad University of Qazvin, Qazvin, Iran. His research interests include optimization models, logistic systems, transportation networks design, transportation planning, and AI algorithms.

Behnam Vahdani was born and raised in Tehran, Iran. He earned his BSc from Azad University, Tehran, Iran (2006), MSc from Azad University, Qazvin, Iran (2009), and PhD from Tehran University, Tehran, Iran (2014), all in Industrial Engineering. $\mathrm{He}$ is currently an Assistant Professor in Industrial Engineering at Azad University of Qazvin, Qazvin, Iran. The main focus of his research is in the area of supply chain network, transportation, metaheuristics, healthcare management, and green and sustainable logistics. 